University of Nebraska - Lincoln

DigitalCommons@University of Nebraska - Lincoln

\title{
Contamination of groundwater under cultivated fields in an arid environment, central Arava Valley, Israel
}

O. Oren

Geological Survey of Israel, orly.oren@mail.gsi.gov.il

Y. Yechieli

Geological Survey of Israel, yechieli@gsi.gov.il

J.K. Bohlke

USGS, jkbohlke@usgs.gov

A. Dody

$N R C N$

Follow this and additional works at: https://digitalcommons.unl.edu/usgsstaffpub

Oren, O.; Yechieli, Y.; Bohlke, J.K.; and Dody, A., "Contamination of groundwater under cultivated fields in an arid environment, central Arava Valley, Israel" (2004). USGS Staff -- Published Research. 558.

https://digitalcommons.unl.edu/usgsstaffpub/558

This Article is brought to you for free and open access by the US Geological Survey at DigitalCommons@University of Nebraska - Lincoln. It has been accepted for inclusion in USGS Staff -- Published Research by an authorized administrator of DigitalCommons@University of Nebraska - Lincoln. 
Journal

of

Hydrology

www.elsevier.com/locate/jhydro

\title{
Contamination of groundwater under cultivated fields in an arid environment, central Arava Valley, Israel
}

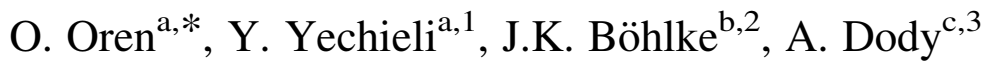 \\ ${ }^{a}$ Geological Survey of Israel, 30 Malchei Yisrael Str., Jerusalem 95501, Israel \\ ${ }^{\mathrm{b}}$ USGS, 431 National Center, Reston, VA 20192, USA \\ ${ }^{\mathrm{c}}$ NRCN, POB. 9001, Beer Sheva 84190, Israel
}

Received 7 May 2003; revised 5 December 2003; accepted 10 December 2003

\begin{abstract}
The purpose of this study is to obtain a better understanding of groundwater contamination processes in an arid environment (precipitation of $50 \mathrm{~mm} / \mathrm{year}$ ) due to cultivation. Additional aims were to study the fate of $\mathrm{N}, \mathrm{K}$, and other ions along the whole hydrological system including the soil and vadose zone, and to compare groundwater in its natural state with contaminated groundwater (through the drilling of several wells).

A combination of physical, chemical, and isotopic analyses was used to describe the hydrogeological system and the recharge trends of water and salts to the aquifers. The results indicate that intensive irrigation and fertilization substantially affected the quantity and quality of groundwater recharge. Low irrigation efficiency of about 50\% contributes approximately $3.5-4$ million $\mathrm{m}^{3} /$ year to the hydrological system, which corresponds to $0.65 \mathrm{~m}$ per year of recharge in the irrigated area, by far the most significant recharge mechanism.

Two main contamination processes were identified, both linked to human activity: (1) salinization due to circulation of dissolved salts in the irrigation water itself, mainly chloride, sulfate, sodium and calcium, and (2) direct input of nitrate and potassium mainly from fertilizers.

The nitrate concentrations in a local shallow groundwater lens range between 100 and $300 \mathrm{mg} / \mathrm{l}$ and in the upper sub-aquifer are over $50 \mathrm{mg} / \mathrm{l}$. A major source of nitrate is fertilizer $\mathrm{N}$ in the excess irrigation water. The isotopic compositions of $\delta{ }^{15} \mathrm{~N}-\mathrm{NO}_{3}(\mathrm{range}$ of 4.9-14.8\%o) imply also possible contributions from nearby sewage ponds and/or manure. Other evidence of contamination of the local groundwater lens includes high concentrations of $\mathrm{K}(20-120 \mathrm{mg} / \mathrm{l})$ and total organic carbon (about $10 \mathrm{mg} / \mathrm{l})$.
\end{abstract} (C) 2004 Elsevier B.V. All rights reserved.

Keywords: Groundwater; Arid environment; Nitrate; N isotope; Contamination; Agriculture

\section{Introduction}

* Corresponding author. Tel./fax: +972-2-5380688.

E-mail addresses: orly.oren@mail.gsi.gov.il (O. Oren), yechieli@mail.gsi.gov.il (Y. Yechieli), jkbohlke@usgs.gov (J.K. Böhlke),dodik@bgumail.bgu.ac.il (A. Dody).

1 Tel./fax: +972-2-5380688.

2 Tel./fax: + 1-703-648-6325.

3 Tel./fax: +972-8-6568911.
Groundwater is a significant or sole source of water in arid areas. Contamination of groundwater due to agricultural activities could therefore severely endanger survival in these harsh environments. This contamination is usually expressed in increasing salinity and nitrate concentrations. 
The quantities and qualities of the recharge water substantially influence the pumping potential from the aquifers in arid environments. The natural source is limited to infiltration during floods, which are characterized by low frequency and irregularity (Simmers, 1997). The anthropogenic sources may be excess of irrigation water and leakage from sewage ponds. Agriculture has had profound effects on the rates and compositions of groundwater recharge (Albus and Knighton, 1998; Rodvang and Simpkins, 2001; Böhlke, 2002).

The effects of irrigation and fertilization in arid zones could be: (1) salinization of the soil and groundwater below the fields (Stigter et al., 1998) and (2) increase of nitrate concentrations in groundwater (Singh et al., 1995; Oenema et al., 1998; Allaire-Leung et al., 2001). Irrigation in arid zones causes an increase of the salt concentrations in the root zone due to high evapotranspiration. In order to minimize soil salinization, excess amounts of water are required, much beyond that needed by the crops (Rhoads and Loveday, 1990). The excess water causes the leaching of the salts to the groundwater. Hence, the presence of agricultural activities introduces a longterm risk of groundwater pollution by excess fertilizers, salts and pesticides leached downward (Hadas et al., 1999). The fertilization efficiency (the fraction of applied $\mathrm{N}$ that is taken up by plants) in the study area was estimated to be about 50\% (Bar-Yosef et al., 1982). The average annual amount of applied $\mathrm{N}$ in the study area is $55 \mathrm{~g} / \mathrm{m}^{2}$. Converting half of this amount to nitrate yields a potential annual nitrate load in recharging groundwater of approximately $120 \mathrm{~g} / \mathrm{m}^{2}$.

Agricultural activities, especially cultivation and fertilization, are principal causes of nitrate contamination on a regional scale (Hudak, 2000; Nolan, 2001). Nitrate is very mobile in groundwater and tends not to adsorb or precipitate on aquifer solids (Hem, 1985). High concentrations of nitrate constitute a health hazard and the American standard for drinking water is $45 \mathrm{mg} / \mathrm{l} \mathrm{NO}_{3}$ (EPA, 1996).

Agricultural application of $\mathrm{K}$ and $\mathrm{P}$ as plant nutrients commonly has less of a signature in groundwater (Böhlke, 2002). The fate of $\mathrm{K}$ is determined in part by ion exchange and sorption by clays hence $\mathrm{K}$ enrichment in groundwater is sporadic. $\mathrm{P}$ is sorbed strongly onto solid phases, hence no high values occur in groundwater.
The purpose of this study is to obtain a better understanding of contamination processes of groundwater related to agriculture activity in an extremely arid environment. The word 'contamination' as used by Freeze and Cherry (1979) implies that human activities have increased the concentration of a constituent, though not necessarily harmful. Additional aims were to study the fate of $\mathrm{N}, \mathrm{K}$, and other ions along the whole hydrological system including the soil and vadose zone, to compare groundwater in its natural state with contaminated groundwater (through the drilling of several wells), among others, and to demonstrate the use of the ${ }^{15} \mathrm{~N}$ isotope in nitrate. A combination of physical, chemical and isotopic analyses was used to explain the hydrological system and the trends of water and salt recharge.

\section{Study area}

The central Arava Valley is located in the southern part of Israel (Fig. 1). The valley is drained to the north by Wadi Arava, which drains wadis from the east (Edom Mountains) and the west (Negev mountains) toward the Dead Sea.

The area is characterized by desert climate. The average yearly precipitation is $50 \mathrm{~mm}$ and the potential evaporation exceeds $3000 \mathrm{~mm}$. The average yearly temperature is $25^{\circ} \mathrm{C}$.

In the area there are several rural settlements with cultivated fields totaling $18 \mathrm{~km}^{2}$. Groundwater is the only source of water for the settlements. Since the 1960s agriculture developed above the formations of the upper aquifers, which contained in the past fresh water of good quality. Eighty percent of the irrigation and drinking water is drawn from the upper aquifers of the Hazeva and Arava formations and the other $20 \%$ is drawn from deep aquifers, mainly from the Lower Cretaceous sandstones of the Kurnub Group (Yechieli et al., 1992; Naor and Granit, 2000). The water from different wells mix before they reach the fields. Over the years, increases in the salt concentrations, and especially nitrate were observed in the groundwater (Naor and Granit, 2000).

The research focused on the fields around the En Yahav settlement as a representative case. This settlement was the first (founded in 1967) and is the biggest, with a cultivated area of $5.6 \mathrm{~km}^{2}$. It was, 


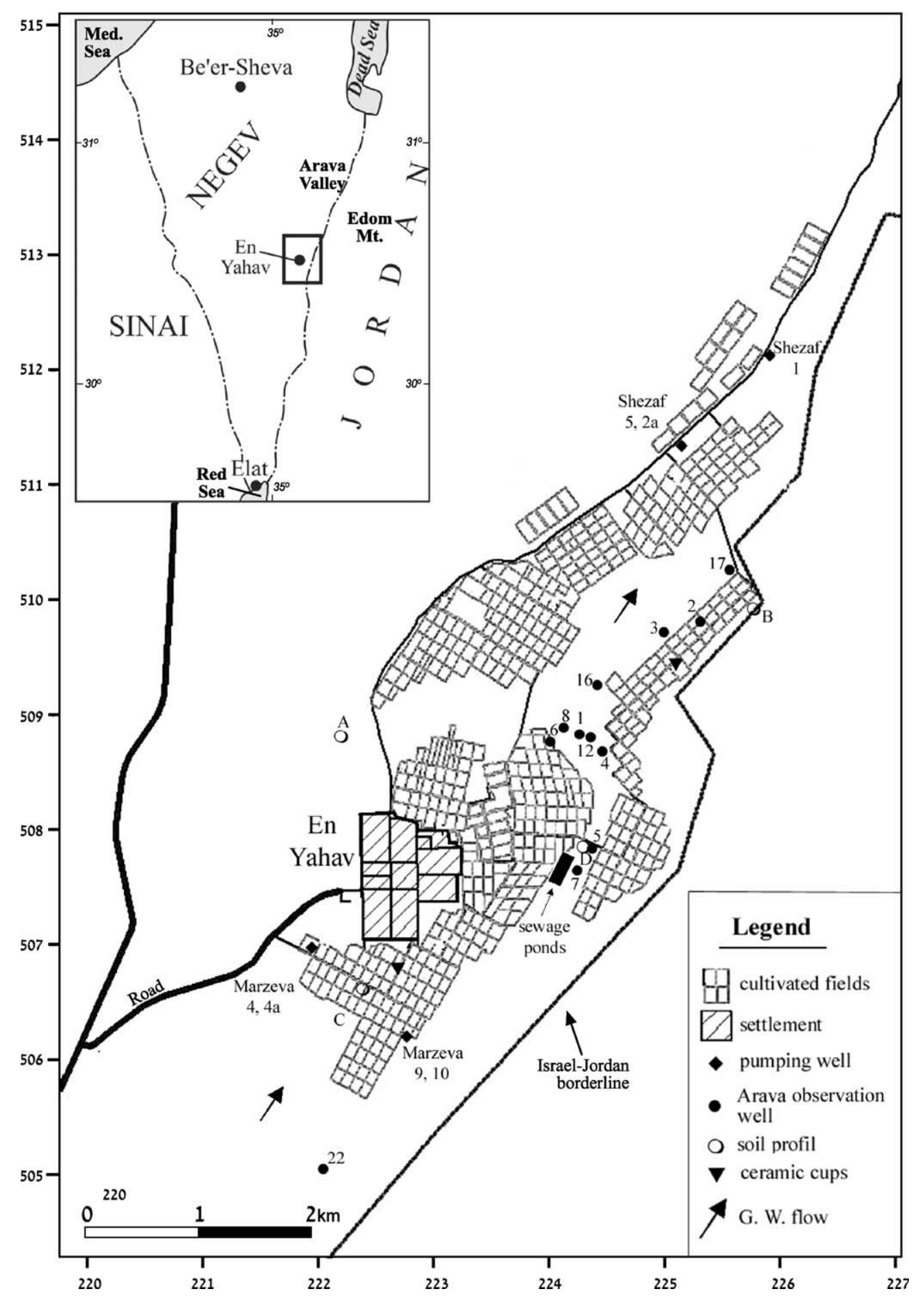

Fig. 1. Location map of the study area in the central Arava Valley. Coordinate in ITM grid. 
therefore, expected that contamination processes would be most notable there.

\section{The hydrologic system}

The upper aquifers include the Neogene Hazeva and the Plio-Pleistocene Arava formations. The Hazeva formation consists mainly of alternating clay and sand beds forming sub-aquifers of limited areal extension due to frequent lateral lithological changes. It is overlain by the Plio-Pleistocene Arava fill aquifer consists of coarse clastic alluvial zones (Yechieli et al., 1992). Fig. 2 shows the typical field relations in

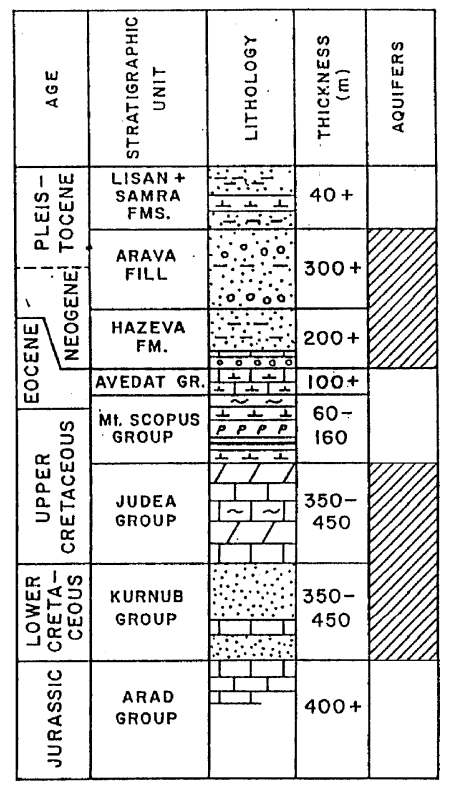

LEGEND

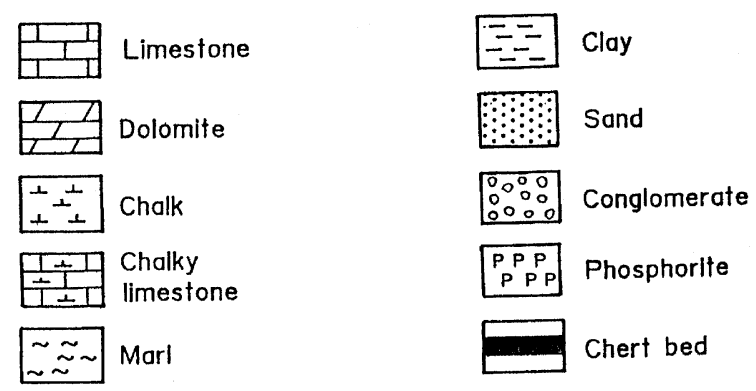

Fig. 2. Generalized stratigraphic column with indication of the main investigated aquifer.

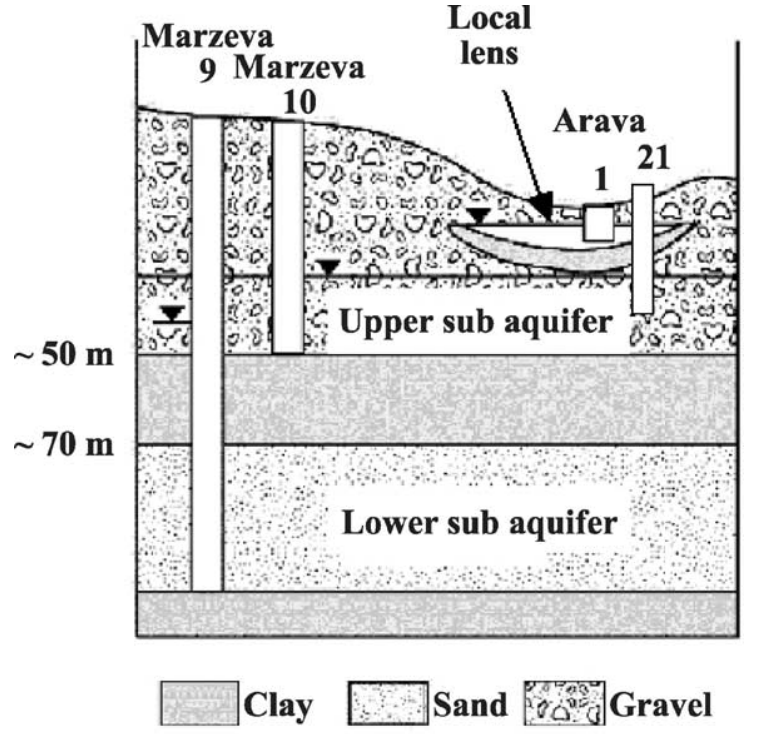

Fig. 3. Schematic geohydrological cross-section in the study area.

the area. The general direction of groundwater flow is NNE, toward the Dead Sea.

The aquifer in the study area is divided by clay layers into two main sub-aquifers (Fig. 3). The lower one is confined whereas the upper is a semi-confined aquifer. The hydraulic head of the upper sub-aquifer is about 2-10 m higher than that of the lower one.

Near the surface, at a depth of $2-5 \mathrm{~m}$ there is a shallow groundwater lens that forms a perched aquifer (Fig. 3) extending over an area of at least $2.5 \mathrm{~km}^{2}$. The hydraulic head of the perched aquifer is at least $2 \mathrm{~m}$ higher than that of the upper sub-aquifer. The groundwater level measurements indicate that the flow direction of all three aquifer units is to the NNE.

\section{Agricultural activity}

The cultivation of the fields in the Arava Valley began in the late 1960s, and the area has evolved into an advanced technological center of agriculture. Agriculture is based on intensive irrigation and fertilization to improve the soils. In recent years most of the fields have been covered with greenhouses. The crops include mainly seasonal crops such as vegetables and flowers but also palm plantations 
and vineyards. The growing season extends generally 10 months a year.

The irrigation regime begins with washing the soils by sprinklers with $50 \mathrm{~m}^{3}$ of water per $1000 \mathrm{~m}^{2}$ of land, equivalent to $50 \mathrm{~mm} / \mathrm{year}$. After that, the irrigation is accomplished by dripping. The entire amount of irrigation water ranges between 1000 and $1500 \mathrm{~m}^{3}$ per $1000 \mathrm{~m}^{2} /$ year (1000-1500 mm/year) depending on the crop type. The total amount of irrigation water is $7.5-8$ million $\mathrm{m}^{3} /$ year.

The fertilizers comprise three major nutrients: nitrogen, phosphorus, and potassium. The amounts applied average around 50-60 g N, 5-6 g P and $40 \mathrm{~g}$ $\mathrm{K}$ per $\mathrm{m}^{2} /$ year, respectively. Moreover, at the beginning of the season, the farmers fertilize the fields with cattle manure, which adds about $20 \mathrm{~g} \mathrm{~N}$, $10 \mathrm{~g} \mathrm{P}$ and $20 \mathrm{~g} \mathrm{~K}$ per $\mathrm{m}^{2}$.

\section{Methodology}

\subsection{Unsaturated zone}

Soil profiles were sampled to a depth of 2-3 $\mathrm{m}$ in cultivated fields, in the flood channel of Wadi Arava, and in undisturbed natural soils. The samples were collected at intervals of $20 \mathrm{~cm}$.

Salts were extracted from the soil samples by drying the soil at $105^{\circ} \mathrm{C}$, sifting it with a $2 \mathrm{~mm}$ sieve to remove the large fractions, dividing the sample randomly by splitter, dissolving the salts with distilled water by shaking for $4 \mathrm{~h}$ (approx, water/soil ratio $=10$, by weight), and filtering the solution before the chemical analysis. The concentrations represent both the dissolved salts in $1 \mathrm{~kg}$ soil and the salts in the soil water. Irrigation water (in text 'irrigation') and irrigation water to which fertilizer has been added (in text 'irrigation + fertilizer') were sampled in the cultivated fields and analyzed.

Ceramic cups were used to sample the water in and below the root zone of cultivated fields. The sampler is a cylindrical ceramic chamber, $6 \mathrm{~cm}$ long with an external diameter of $2 \mathrm{~cm}$ and inner diameter of $1.7 \mathrm{~cm}$; it has a maximum pore size of $2-3 \mu \mathrm{m}$. The ceramic cup is attached to a PVC pipe and the opposite end is sealed with a one-hole stopper with tubing and clamp so that air can be evacuated from the sampler. The buried porous cup collects a sample of soil water when the vacuum in the sampler exceeds the adjacent soil moisture tension (Hansen and Harris, 1975).

Nine samplers were inserted in the soil in three different greenhouses, and in each one, at different soil depths-20, 40-60, 80-120 cm. Samples were collected every few days during the agriculture season.

\subsection{Saturated zone}

Eighteen shallow boreholes (2.5-5 m depth) were drilled to the local groundwater lens between June and August 2001 (Fig. 1). Another five deeper boreholes were drilled in June 2002 to the local lens and to the upper sub-aquifer, at the center of the lens and at an upgradient location south of the fields (Arava 22 well).

Groundwater was also sampled from pumping wells located at three sites near the fields (Fig. 1); at every site there were two wells, one extracting from the upper sub-aquifer and the other from the lower sub-aquifer. The 'unpolluted wells' are wells that extract water from the same regional aquifer, some kilometers from the agricultural area and have low salt concentrations, similar to the natural composition before the settlement was built.

Throughout the year (June 2001 - August 2002) all the observation and pumping wells in the study area were sampled several times, and temperature and electrical conductivity were measured. Water levels in the shallow observation boreholes were measured regularly every $2-3$ weeks.

\subsection{Chemical and isotopic analyses}

The chemical analyses and $\delta{ }^{18} \mathrm{O}$ analyses in water were conducted at the Geological Survey of Israel. Major cations were analyzed on a Perkin Elmer Optima 3300 ICP AES. Anion concentrations were measured using a Dionex Series 4000I Gradient Ion Chromatography and HPLC. Only analyses with charge balance $<3 \%$ were used in this study. Oxygen isotope analyses of water were done by the VG SIRA II IRMS mass spectrometer with an analytical error of $0.1 \%$.

Tritium concentrations were determined at the Weizmann Institute following enrichment using 
an electrolysis system, by a low-level counting system, LKB 1220 Quantulus scintillation counter (Bowman and Hughes, 1981). Tritium concentrations are expressed in Tritium Units (TU) with an analytical error of $\pm 0.2 \mathrm{TU}$.

Isotopic analyses of nitrogen $\left(\delta^{15} \mathrm{~N}\right)$ in nitrate were done at the USGS laboratory in Reston, Virginia. Nitrate samples and standards were prepared by freeze-drying and off-line combustion techniques for mass spectrometry, and the data were normalized to values of $+0.4 \%$ o for IAEA-N1 and $+180 \%$ o for USGS-32 (Böhlke and Denver, 1995; Böhlke and Coplen, 1995; Böhlke et al., 2002), with average reproducibility of \pm 0.1 to 0.2 .

Analyses of total organic carbon (TOC) were done at the laboratory of the Israeli Ministry of Health. The analysis is based on the combustion-infrared method (Eaton et al., 1995), performed by the TOC analyzer, $5000 \mathrm{~A}$, Shimadzu. The precision of the method limits is $5-10 \%$.

\section{Results}

The chloride, sulfate, and nitrate content in the soil profiles of natural soil, cultivated fields, and Wadi Arava (profiles A, C, D, respectively, Fig. 1) are presented in Fig. 4. The ionic concentrations are expressed in $\mathrm{g} / \mathrm{kg}$-dried soil. The ion concentrations in the natural soil are two orders of magnitude higher than the concentrations in the cultivated fields and Wadi Arava. The chloride and sulfate concentrations in the natural soil are around $10 \mathrm{~g} / \mathrm{kg}$ while in the other profiles the chloride concentrations are below $0.1 \mathrm{~g} / \mathrm{kg}$ and the sulfate concentrations are around $0.1 \mathrm{~g} / \mathrm{kg}$. The nitrate concentration in the natural soil is about $1 \mathrm{~g} / \mathrm{kg}$ while in the cultivated fields and Wadi Arava it is around $0.01 \mathrm{~g} / \mathrm{kg}$. Some of the excavations in the cultivated fields had water of the shallow lens at a depth of 2-3 $\mathrm{m}$ and their profiles were quite wet.

The water table depth of the shallow lens rises by about 30-40 cm during the irrigation season, from September to March (Fig. 5) and then drops again till August.

Chemical and isotopic analyses of selected samples of irrigation water, irrigation + fertilizer water, soil water in and below the root zone (ceramic cups), and groundwater from the three sub-aquifers

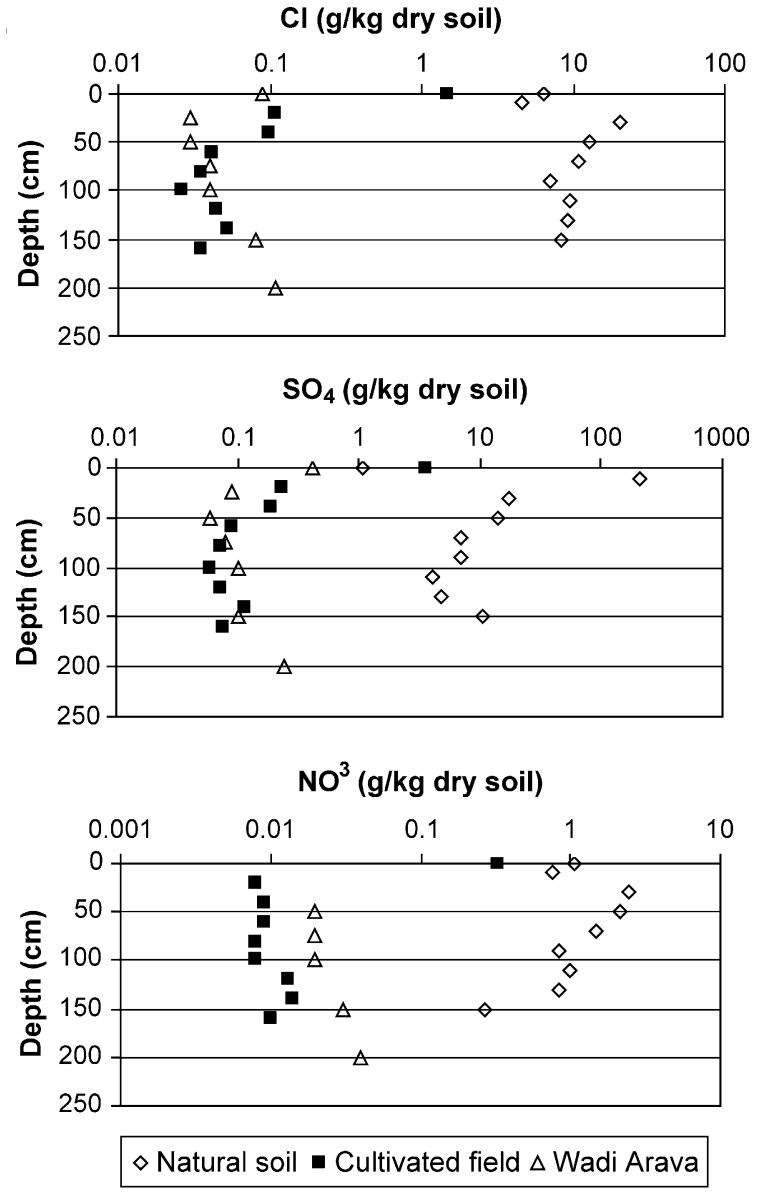

Fig. 4. Ions profiles $\left(\mathrm{Cl}, \mathrm{SO}_{4}\right.$ and $\left.\mathrm{NO}_{3}\right)$ in the unsaturated zone of the study area: in undisturbed natural soil (A), a cultivated field (C) and in Wadi Arava (D) (locations in Fig. 1).

are presented in Table 1 . When plotting concentrations of several ions versus $\mathrm{Cl}$, the groundwater samples show a mixing line between groundwater from the local lens, which is highly contaminated, and groundwater from the lower sub-aquifer, which is mainly uncontaminated (Fig. 6). The upper subaquifer is less contaminated and has intermediate values. In the upper sub-aquifer the salt concentrations in the upgradient wells are lower than those of the downgradient wells (Table 1). The $\mathrm{Cl}, \mathrm{SO}_{4}$ and other ionic concentration values of the water from the ceramic cups are in the same range as the local lens values. The irrigation + fertilizer water have the same concentrations of $\mathrm{Cl}, \mathrm{SO}_{4}, \mathrm{Mg}, \mathrm{Na}, \mathrm{Ca}$ as the irrigation 


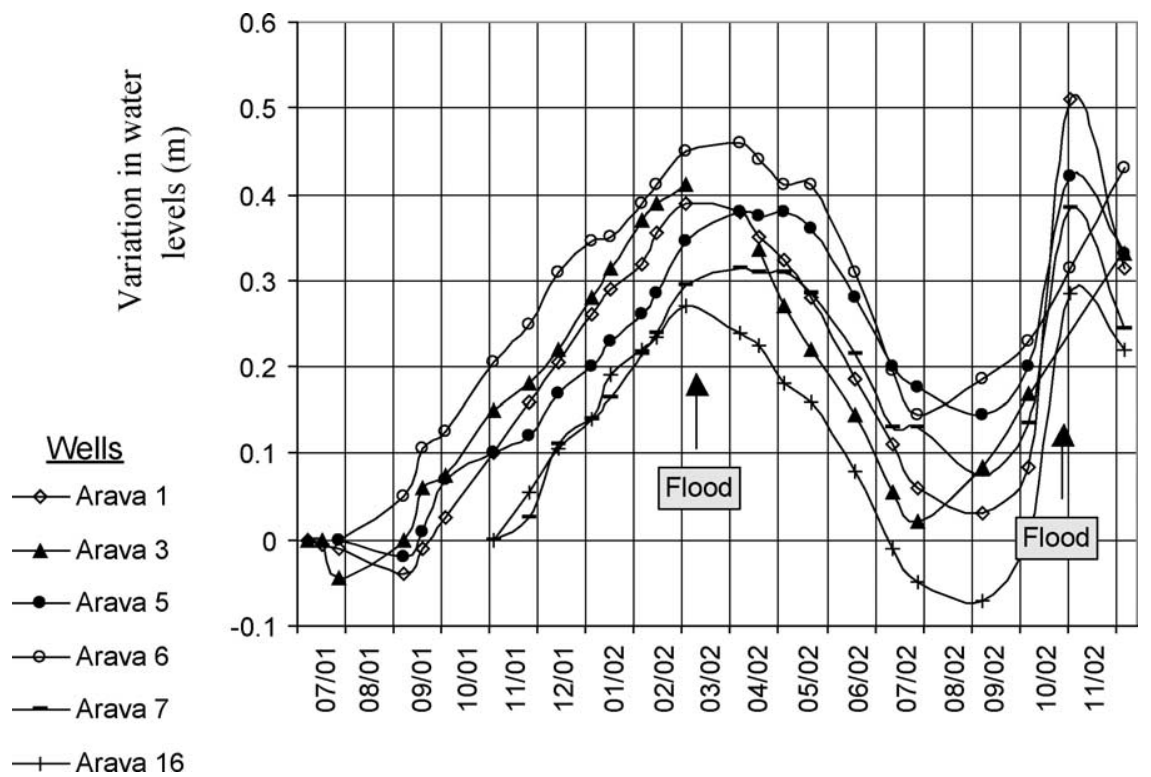

Fig. 5. Variation in water levels in selected boreholes of the shallow lens. Values of the water table are relative to the first measurement.

water but much higher concentrations of $\mathrm{NO}_{3}$ and $\mathrm{K}$ (Figs. 6 and 7, Table 1).

The nitrate and chloride concentrations over a period of about 13 years in three boreholes located at the southern side of the fields are presented in Fig. 8. In the lower sub-aquifer (Marzeva 9), the nitrate and chloride concentrations are low and have been constant over the years. The nitrate concentrations are lower than $10 \mathrm{mg} / \mathrm{l}$ and the chloride concentrations are about $250 \mathrm{mg} / \mathrm{l}$. In contrast, in Marzeva 10 and 4, which extract water from the upper sub-aquifer, concentrations are higher and have increased for nitrate over the years, mainly since 1999 . The chloride concentrations in Marzeva 4 have also increased (corresponding with the nitrate increase) but in Marzeva 10, variations of the chloride concentrations were found.

Fig. 9 presents the nitrate concentration ranges in the three aquifer units and in the ceramic cups. The nitrate values of the ceramic cups have the largest range, between 150 and $700 \mathrm{mg} / \mathrm{l}$, depending on the fertilization efficiency and the variability in the soil. The nitrate concentrations in the local lens, between 100 and $300 \mathrm{mg} / \mathrm{l}$, far exceed the standard for drinking water. The range in the lower sub-aquifer, between 5 and $35 \mathrm{mg} / \mathrm{l}$, reveal the presence of nitrate at deeper groundwater levels.
The potassium concentrations in the three aquifer units and in the ceramic cups are presented in Fig. 10. There is a large variability of the potassium concentration in the ceramic cups and in the lens close to the surface.

Another component with relatively high concentrations in the local lens is the TOC. The TOC values in the groundwater in the local lens are around $10 \mathrm{ppm}$ while in the unpolluted wells they are about $0.4 \mathrm{ppm}$ (Table 1). Water in one of the boreholes to the local lens (Arava 16) has a value of about 200 ppm, which probably represents a local source of organic matter. It also has exceptionally high concentrations of salts, TDS around $30,000 \mathrm{mg} / \mathrm{l}$, therefore it is not represented as a sample of the local lens in Figs. 6-7, 9, and 10. The TOC value in the upper sub-aquifer is little higher than in the unpolluted wells; values of $0.6-0.8$ compared to $0.4 \mathrm{ppm}$.

The isotopic values of $\delta^{18} \mathrm{O}$ of the groundwater ranged between -4.3 and $-5.2 \%$ (Table 1 ), similar to values found in former works, e.g. Gat and Galai (1982).

The isotopic composition of nitrogen in nitrate was also measured in some of the samples (Table 1). The unpolluted wells, with low concentration of nitrate (below $10 \mathrm{mg} / \mathrm{l}$ ), have $\delta^{15} \mathrm{~N}$ values of 6.7 and $7.0 \%$. Nitrate leached from the virgin natural soil has 
Table 1

Chemical and isotopic analyses of selected samples

\begin{tabular}{|c|c|c|c|c|c|c|c|c|c|c|c|c|c|c|c|c|c|c|c|c|}
\hline Name & Description & Date & $\begin{array}{l}\mathrm{Na} \\
(\mathrm{mg} / \mathrm{l})\end{array}$ & $\begin{array}{l}\mathrm{K} \\
(\mathrm{mg} / \mathrm{l})\end{array}$ & $\begin{array}{l}\mathrm{Ca} \\
(\mathrm{mg} / \mathrm{l})\end{array}$ & $\begin{array}{l}\mathrm{Mg} \\
(\mathrm{mg} / \mathrm{l})\end{array}$ & $\begin{array}{l}\mathrm{Cl} \\
(\mathrm{mg} / \mathrm{l})\end{array}$ & $\begin{array}{l}\mathrm{SO}_{4} \\
(\mathrm{mg} / \mathrm{l})\end{array}$ & $\begin{array}{l}\mathrm{HCO}_{3} \\
(\mathrm{mg} / \mathrm{l})\end{array}$ & $\begin{array}{l}\mathrm{NO}_{3} \\
(\mathrm{mg} / \mathrm{l})\end{array}$ & $\begin{array}{l}\mathrm{Br} \\
(\mathrm{mg} / \mathrm{l})\end{array}$ & $\begin{array}{l}\mathrm{Sr} \\
(\mathrm{mg} / \mathrm{l})\end{array}$ & $\begin{array}{l}\text { TDS } \\
(\mathrm{mg} / \mathrm{l})\end{array}$ & $\begin{array}{l}\text { TOC } \\
(\mathrm{mg} / \mathrm{l})\end{array}$ & $\begin{array}{l}\delta^{15} \mathrm{~N}_{\mathrm{NO}_{3}} \\
(\%)\end{array}$ & $\begin{array}{l}\delta^{18} \mathrm{O}_{H_{2}} \mathrm{O} \\
(\% \circ)\end{array}$ & $\begin{array}{l}\text { Tritium } \\
\text { (TU) }\end{array}$ & $\begin{array}{l}\mathrm{Na} / \mathrm{Cl} \\
\text { (eq./eq.) }\end{array}$ & $\begin{array}{l}\mathrm{K} / \mathrm{Cl} \\
\text { (eq.leq.) }\end{array}$ & $\begin{array}{l}\mathrm{NO}_{3} / \mathrm{Cl} \\
\text { (eq.leq.) }\end{array}$ \\
\hline Asa field & & 09/10/01 & 226 & 14 & 201 & 97 & 383 & 526 & & 29 & 1.4 & 6.0 & 1486 & & & & & 0.91 & 0.03 & 0.04 \\
\hline Oren field & $\begin{array}{l}\text { Irrigation + } \\
\text { fertilizer } \\
\text { water }\end{array}$ & $18 / 06 / 01$ & 180 & 125 & 169 & 74 & 314 & 479 & 255 & 323 & $<1.0$ & 4.4 & 2009 & & & -5.8 & & 0.89 & 0.36 & 0.59 \\
\hline Saker field & & $10 / 10 / 01$ & 262 & 92 & 196 & 95 & 400 & 480 & & 255 & 1.7 & 6.0 & 1842 & & & & & 1.01 & 0.21 & 0.36 \\
\hline $\begin{array}{l}\text { Ceramic } \\
\text { cup: } 40 \mathrm{~cm}\end{array}$ & & 09/10/01 & 293 & 66 & 367 & 129 & 475 & 855 & & 215 & 2.4 & 10.5 & 2417 & & 2.7 & $-5.3^{\mathrm{a}}$ & & 0.86 & 0.07 & 0.32 \\
\hline $\begin{array}{l}\text { Ceramic } \\
\text { cup: } 80 \mathrm{~cm}\end{array}$ & $\begin{array}{l}\text { Soil water } \\
\text { below } \\
\text { the root } \\
\text { zone }\end{array}$ & $06 / 12 / 01$ & 361 & 127 & 643 & 117 & 664 & 1680 & 200 & 186 & 3.9 & 10.5 & 3987 & & & & & 0.84 & 0.17 & 0.16 \\
\hline $\begin{array}{l}\text { Ceramic } \\
\text { cup: } 60 \mathrm{~cm}\end{array}$ & & $06 / 12 / 01$ & 312 & 98 & 745 & 130 & 613 & 1670 & 260 & 423 & 3.6 & 8.6 & 4261 & & & & & 0.78 & 0.15 & 0.39 \\
\hline Arava 3 & & $10 / 09 / 01$ & 610 & 102 & 545 & 231 & 930 & 1690 & 450 & 142 & 11.0 & 10.4 & 4723 & & & -4.7 & & 1.01 & 0. & 0.09 \\
\hline Arava 4 & & 09/01 & 370 & 26 & 353 & 155 & 635 & 102 & 29 & & 10.0 & 8.6 & 297 & & & & & & & 09 \\
\hline Arava 5 & & $10 / 09 / 01$ & 362 & 22 & 370 & 166 & 512 & 137 & 20 & & 6. & & 3209 & & 5.5 & $-4.8^{\mathrm{c}}$ & & & & 12 \\
\hline Arava 6 & & $09-10 / 01$ & 776 & 67 & 638 & 325 & 1365 & 2150 & 540 & 105 & 10.5 & 15.9 & 5989 & $7.6^{\mathrm{b}}$ & 14.8 & -4.9 & 0.5 & 0.88 & 0.04 & 0.04 \\
\hline Arava 6 & & 08/04/02 & 470 & 42 & 490 & 218 & 707 & 1600 & 337 & 175 & 12.4 & 7.4 & 4059 & & 10.2 & & & 1.02 & 0.05 & 0.14 \\
\hline Arava 7 & & $08 / 04 / 02$ & 429 & 34 & 450 & 206 & 651 & 1662 & 205 & 209 & 8.2 & 11.3 & 3865 & $9.06^{\mathrm{b}}$ & 5.4 & & & 1.02 & 0.05 & 0.18 \\
\hline Arava 16 & & 08/04/02 & 6834 & 468 & 707 & 1326 & 9480 & 6934 & 2320 & 422 & 20.0 & 19.1 & 28148 & $212.4^{\mathrm{b}}$ & & & & 1.11 & 0.04 & 0.03 \\
\hline Arava 17 & & $08 / 04 / 02$ & 488 & 74 & 625 & 219 & 780 & 1940 & 220 & 273 & 15.1 & 12.5 & 4647 & $7.6^{\mathrm{b}}$ & 6.7 & & & 0.97 & 0.09 & 0.20 \\
\hline Arava 22 & $\begin{array}{l}\text { Upper sub- } \\
\text { aquifer }\end{array}$ & $20 / 06 / 02$ & 155 & 7 & 152 & 60 & 238 & 448 & 222 & $<5$ & $<5$ & 3.9 & 1286 & & & & & 1.00 & 0.03 & $<0.01$ \\
\hline Marzeva 10 & & $14 / 10 / 01$ & 247 & 11 & 218 & 99 & 415 & 630 & 229 & 80 & 1.8 & 6.1 & 1937 & $0.64^{\mathrm{b}}$ & 5.3 & $-4.8^{\mathrm{d}}$ & $1.2^{\mathrm{d}}$ & 0.92 & 0.02 & 0.11 \\
\hline Marzeva 10 & & $08 / 04 / 02$ & 252 & 11 & 232 & 103 & 446 & 644 & 222 & 76 & 3.7 & 6.2 & 1996 & & 4.9 & & & 0.86 & 0.02 & 0.10 \\
\hline Marzeva 4 & & $14 / 10 / 01$ & 245 & 14 & 202 & 100 & 450 & 570 & 232 & 44 & $<1.0$ & 6.2 & 1863 & & 5.7 & $-4.9^{\mathrm{d}}$ & $1.3^{\mathrm{d}}$ & 0.84 & 0.03 & 0.05 \\
\hline Shezaf 5 & $\begin{array}{l}\text { Upper sub- } \\
\text { aquifer } \\
\text { downstream }\end{array}$ & $14 / 10 / 01$ & 462 & 20 & 337 & 160 & 730 & 1100 & 239 & 140 & 3.8 & 9.9 & 3202 & $0.79^{\mathrm{b}}$ & 9.2 & $-4.5^{\mathrm{d}}$ & $1.2^{\mathrm{d}}$ & 0.98 & 0.02 & 0.11 \\
\hline
\end{tabular}




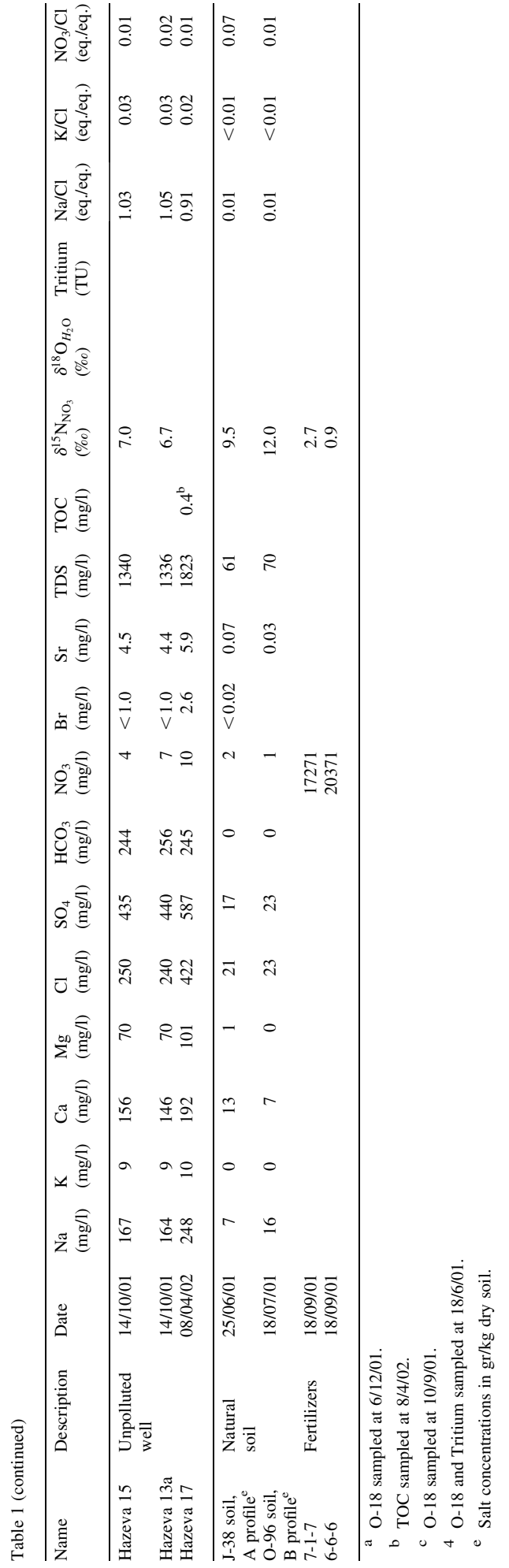

somewhat higher $\delta{ }^{15} \mathrm{~N}$ values of 9.5 and $12.0 \%$. This overall range of values $(\sim 7-12 \%)$ is considered most likely to represent natural nitrate derived from soil organic matter (Densmore and Böhlke, 2000).

In contrast, the fertilizer nitrates have $\delta{ }^{15} \mathrm{~N}$ values close to zero $(0.9$ and $2.7 \%$ ) and nitrate in the drainage water from the root zone (ceramic cups, $20-40 \mathrm{~cm}$ depth) has an isotopic composition similar to that of the fertilizers used above (Table 1).

The polluted boreholes have a wide range of $\delta{ }^{15} \mathrm{~N}$ values, between 4.9 and $14.8 \%$. The boreholes upgradient from the sewage ponds (Fig. 1) have lower values $(4.9-6.2 \%$ o) than the natural nitrate, while the downgradient boreholes have $\delta{ }^{15} \mathrm{~N}$ values in the range of $5.5-14.8 \%$, some of which are higher than the values in unpolluted wells. There is no clear relation between $\delta^{15} \mathrm{~N}$ values and either nitrate or chloride concentrations (Fig. 11).

\section{Discussion}

The results of this study indicate that intensive irrigation in an arid environment significantly affects the groundwater recharge. Low irrigation efficiency contributes large additions of water to the hydrological system. The recharge coefficient of the irrigation water was estimated from the salt concentration factor. This was calculated by dividing the ion concentration in the local groundwater lens by the ion concentration in the irrigation water. The calculation was made only for ions that are considered conservative and not uptaken by plants. Almost the same factor, of about 2.2, was found for $\mathrm{Cl}, \mathrm{Na}, \mathrm{Mg}$ and $\mathrm{Sr}$, indicating that $55 \%$ of the water is lost by evapotranspiration and the rest $45 \%$ infiltrates towards the groundwater. This means that from the 7.5-8 million $\mathrm{m}^{3}$ of irrigation water per year, about 3.6 million $\mathrm{m}^{3}$ infiltrates every year. Within the irrigated area, this is equivalent to about $0.65 \mathrm{~m}$ per unit area.

The infiltrating water from the fields is expected to raise the water table level. Indeed, there is a rise in the water table of the local lens of about $30-40 \mathrm{~cm}$ from September to March (Fig. 5). Although, this rise is much smaller than the expected value, $1.3 \mathrm{~m}$ in September-March (calculation was done by dividing the excess irrigation water by porosity), it can be explained by down flow of $70 \%$ of the recharge 

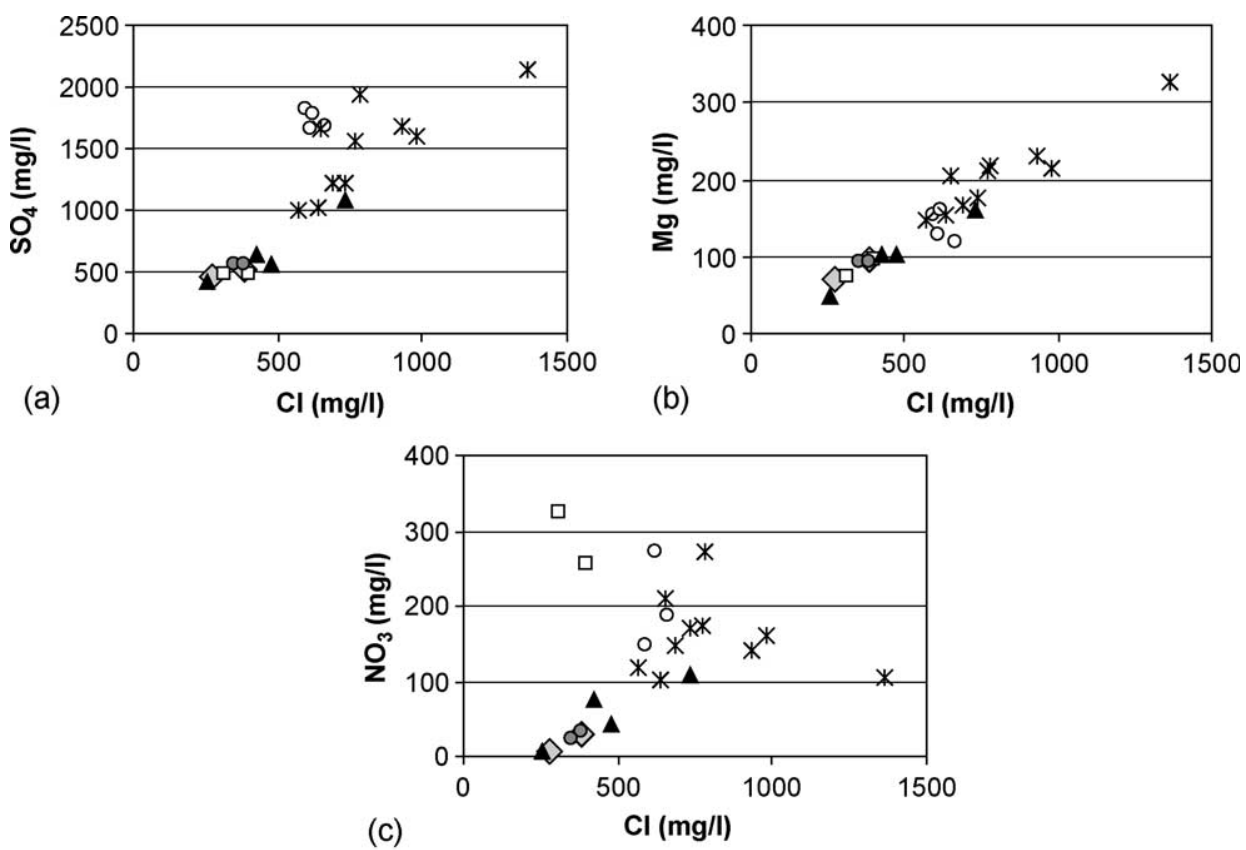

\begin{tabular}{|lll|}
\hline Dirrigation water & O ceramic cups & $\boldsymbol{\Delta}$ upper sub aquifer \\
airrigation + fertilizers water & $*$ local lens & ○ lower sub aquifer \\
\hline
\end{tabular}

Fig. 6. $\mathrm{SO}_{4}, \mathrm{Mg}$, and $\mathrm{NO}_{3}$ concentrations versus $\mathrm{Cl}$ concentrations for several water types (aquifers). $\mathrm{Note}$ that $\mathrm{Cl}, \mathrm{Mg}$, and $\mathrm{SO} 4$ concentrations fall on a mixing line between the lower sub aquifer, through the upper sub aquifer, and the local lens.
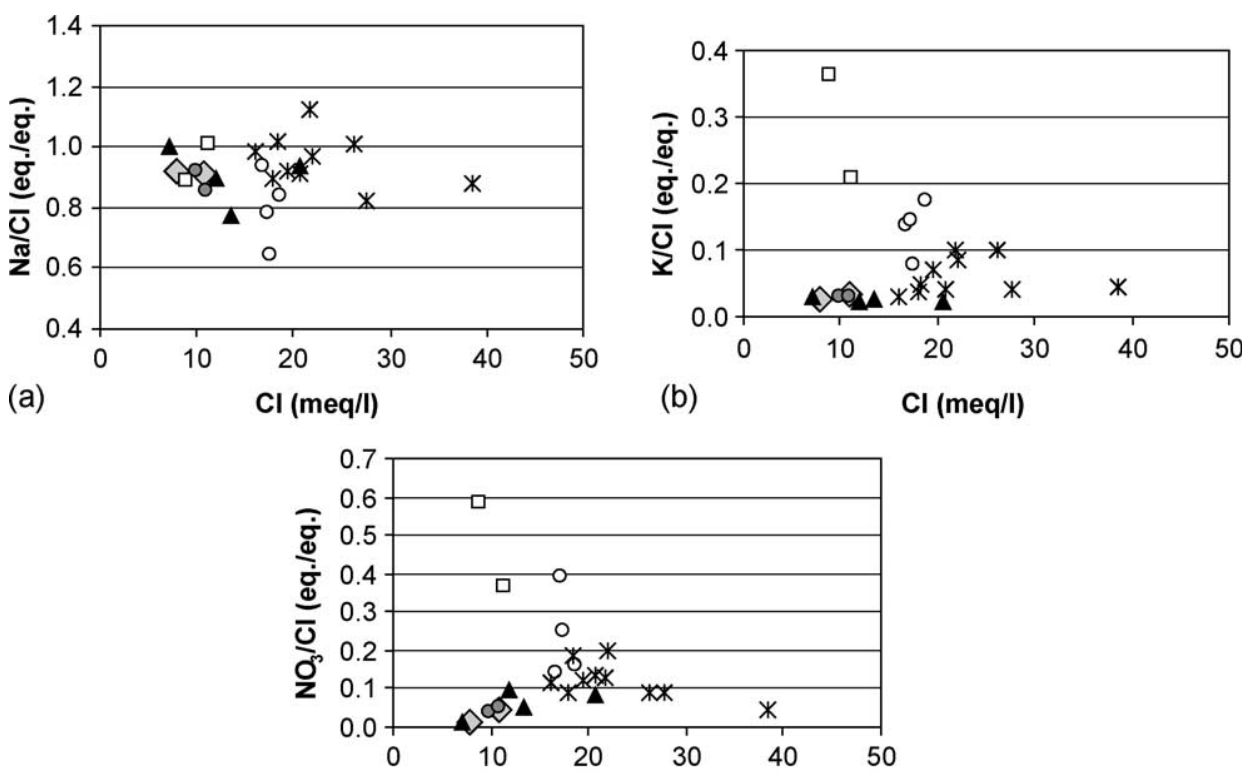

(c)

$\mathrm{Cl}$ (meq/I)

\begin{tabular}{|llll|}
\hline$\diamond$ irrigation water & $\circ$ ceramic cups & $\Delta$ & upper sub aquifer \\
airrigation + fertilizers water & $*$ local lens & $\circ$ & lower sub aquifer \\
\hline
\end{tabular}

Fig. 7. Ion equivalent ratios versus $\mathrm{Cl}$ concentrations for several water types (aquifers). 

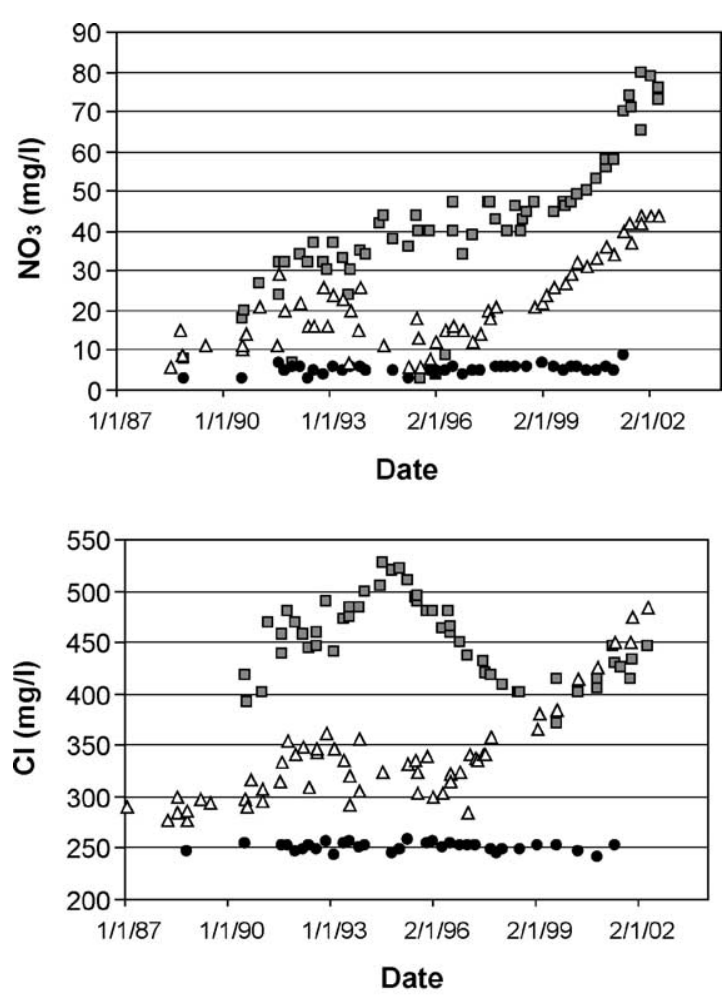

- Marzeva $10 \bullet$ Marzeva $9 \Delta$ marzeva 4

Fig. 8. Nitrate and chloride concentrations in the years 1987-2002 in three wells: Marzeva 10 and 4, upper sub-aquifer; Marzeva 9, lower sub-aquifer. amount towards the upper sub-aquifer. The water level drop from April to August can be explained by decrease of the irrigation amounts and increase of the evapotranspiration rate. The water level decrease means that the recharge rate is less than the downward flow rate from the local lens to the upper sub-aquifer. The dependence of the water table on irrigation activity indicates that this is the main recharge source to the local lens.

The natural recharge from floods depends on the rainfall in the whole basin each year. However, it is difficult to estimate how much water reaches the water table from this source. The natural recharge seems negligible in comparison to the recharge from irrigation, at least in the period from September 2001 to November 2002. In that period only two flash floods crossed the study area in Wadi Arava for about 24-36 h, above and alongside the shallow boreholes. According to the small decrease in groundwater temperature and to the temporary water level rise below the stream in the second flow, it seems that waters from the floods reached the water table, but their contribution, relative to the recharge from irrigation, was insignificant. Recharge from excess irrigation water was also found to be most significant in Sacramento Valley, California $(80 \%$ of the recent recharge, Criss and Davisson, 1996).

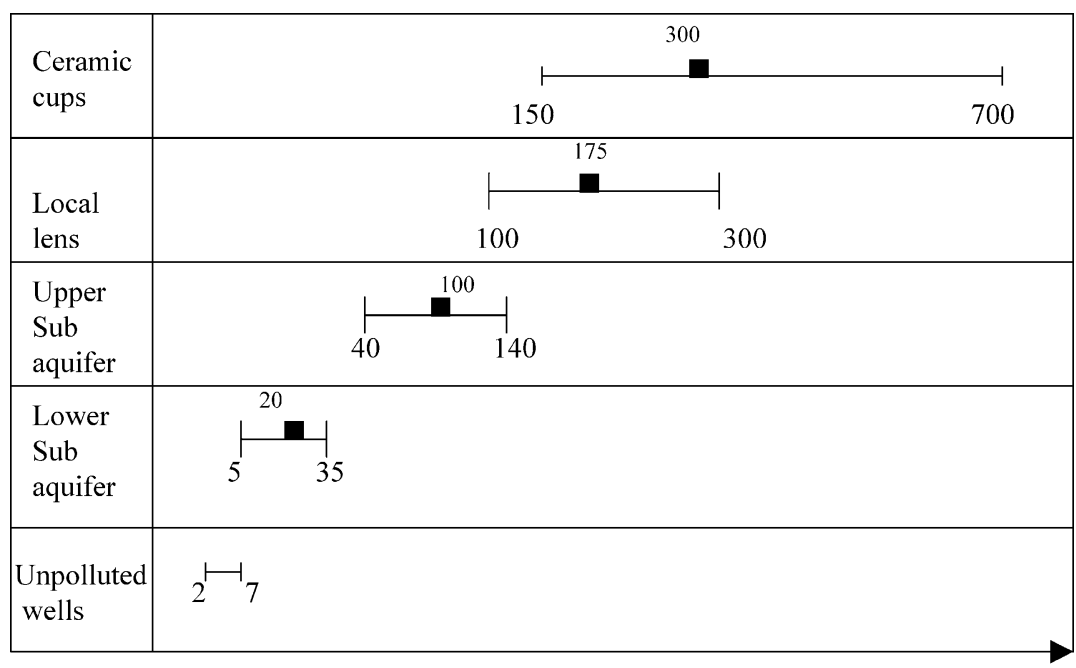

$\mathrm{NO}_{3}(\mathrm{mg} / \mathrm{l})$

Fig. 9. Nitrate concentration ranges and average (squares) of the three aquifer units, unpolluted wells and ceramic cups. 


\begin{tabular}{|c|c|c|c|}
\hline $\begin{array}{l}\text { Ceramic } \\
\text { cups }\end{array}$ & $\vdash_{47}$ & & -1325 \\
\hline $\begin{array}{l}\text { Local } \\
\text { lens }\end{array}$ & $\left.\right|_{13}$ & +115 & \\
\hline $\begin{array}{l}\text { Upper } \\
\text { Sub } \\
\text { aquifer }\end{array}$ & $\left.\right|_{10} \stackrel{15}{ }$ & & \\
\hline $\begin{array}{l}\text { Lower } \\
\text { Sub } \\
\text { aquifer }\end{array}$ & $\left.\right|_{12 \quad 14} ^{13}$ & & \\
\hline
\end{tabular}

Fig. 10. Potassium concentration ranges and average (squares) of the three aquifer units and the drainage water below the root zone (below $60 \mathrm{~cm}$ ) from ceramic cups.
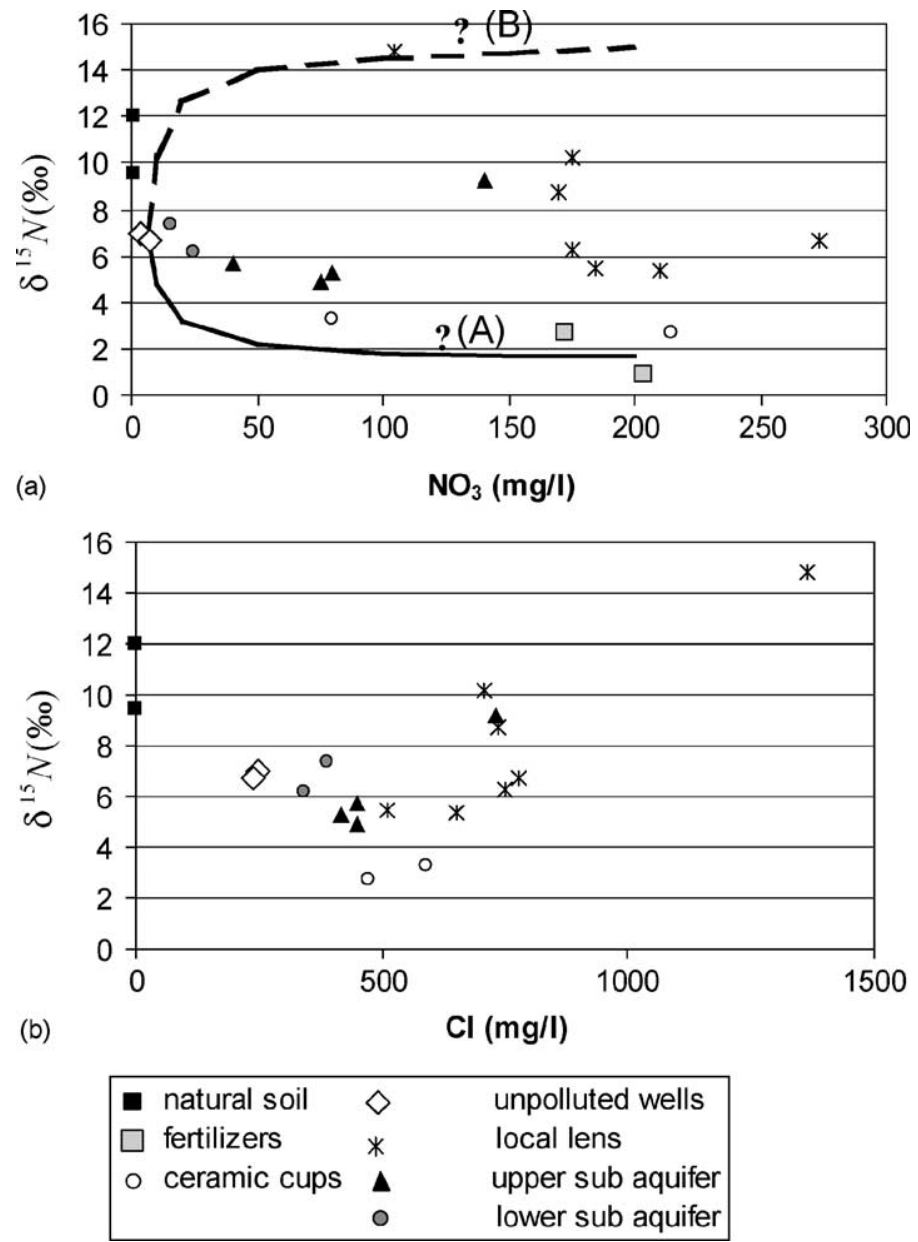

Fig. 11. $\delta^{15} \mathrm{~N}$ values against $\mathrm{NO}_{3}$ and $\mathrm{Cl}$ of selected samples. The ion concentrations of the soils cannot be expressed in mg/l so they are out of the scale. Line A represents a hypothetical mixture between natural groundwater and excess "irrigation + fertilizer" water, and line B represents a hypothetical mixture between natural groundwater and sewage or manure source. 
The tritium concentrations also confirm that the main recharge comes from irrigation water, whose source is regional groundwater, and not from the floods. This is indicated by low tritium concentration in the shallow groundwater in the studied area (e.g. $0.5-1.3 \mathrm{TU}$ in the local lens), which is similar to the values in the regional aquifers (Yechieli et al., 1997) but different from those in modern flood waters (4.1-6 TU, Yechieli et al., 2001).

Unlike the tritium, the stable isotopic composition of the water does not help to distinguish between the recharge sources. According to Yechieli et al. (2001) the $\delta^{18} \mathrm{O}$ values of the rains in the Arava Valley ranges between -2.8 and $-7.5 \%$ (average of $-4.9 \%$ ) and those of the floods, between -5.1 and $-6.6 \%$. These values are close to the values of the irrigation and ceramic cups waters that were measured in this work $(-5.3$ to $-5.9 \%$ o). Therefore, the different sources cannot be distinguished by the $\delta^{18} \mathrm{O}$ composition.

The somewhat higher $\delta^{18} \mathrm{O}$ values of the local lens $(-4.3$ to $4.9 \%$ ) related to the recharge sources may indicate some evaporation during infiltration in the unsaturated zone. The correlation between $\delta^{18} \mathrm{O}$ values and $\mathrm{Cl}, \mathrm{SO}_{4}$ and $\mathrm{NO}_{3}$ concentrations (Oren, 2003) may indicate recharge of evaporative irrigation water, such as found in the Sacramento Valley by Davisson and Criss (1993).

In the cultivated fields and Wadi Arava there is a flushing process, indicated by the low salt concentrations in the soil profiles, while in the undisturbed natural soil there is a salt accumulation process (Fig. 4). Displacement of the salt below $2-2.5 \mathrm{~m}$ in the cultivated fields proves that the water infiltrates below this level towards the water table. Under a significant part of the fields, the shallow water table of the local lens is located $2-5 \mathrm{~m}$ below the surface; hence the salts reach the groundwater rapidly. It is, therefore, reasonable to maintain that irrigation water recharges the groundwater. The presence of salts, including gypsum and halite near the surface in the undisturbed natural soil, is typical in arid regions, where flushing by rain is negligible.

The effect of salinization in the Arava Valley due to recharge by excess irrigation water was previously reported in several preliminary works (Naor and Granit, 1991, 2000). The results of the present study indicate that intensive irrigation and fertilization significantly affect the groundwater quality by two main contamination processes: (1) salinization due to circulation of salts dissolved in the irrigation water itself, mainly chloride, sulfate, sodium and calcium, and (2) direct input of nitrate and potassium from fertilizers and sewage ponds.

The behavior of the main ions in the irrigation water (e.g. chloride, sulfate, magnesium, sodium and calcium) is conservative, while the fertilizer ions (nitrate and potassium) concentrations are reduced because they are uptaken by plants. Whereas the salt concentration factor due to evapotranspiration of the 'irrigation + fertilizers' water is about 2.2, the nitrate and potassium concentration factors are less than 1 ( 0.7 and 0.5 , respectively). This difference is consistent with selective uptake of nitrate and potassium by plants and also potassium sorption by clays.

One of the most important problems related to irrigation in arid zones, where groundwater tends to be brackish or saline, is the recycling of salts. Salts in groundwater that is used for irrigation penetrate to the aquifer system again after evapotranspiration with higher concentration. The major salts are not taken up substantially by plants and therefore eventually reach the water table. It is possible to estimate the salt mass addition by multiplying the chloride concentration in the irrigation water $(370 \mathrm{mg} / \mathrm{l})$ and the irrigation water volume (about $1.4 \mathrm{~m}^{3} / \mathrm{m}^{2}$ ), yielding about $520 \mathrm{~g} / \mathrm{m}^{2}$ of chloride per year. A similar calculation yields an addition of $280 \mathrm{~g} / \mathrm{m}^{2}$ sodium, $740 \mathrm{~g} / \mathrm{m}^{2}$ sulfate and $280 \mathrm{~g} / \mathrm{m}^{2}$ calcium per year. The same process of salt circulation was found in a semi-arid area in Portugal, where the excess evaporative irrigation water caused chloride concentration increase, ion exchange and calcite precipitation (Stigter et al., 1998). These hydrochemical processes and possibly also dissolution might occur in the case herein too, but are not very significant

The inverse relation between the depth of the aquifer units and the ion concentrations indicates that the contamination comes from the surface. This conclusion can be shown from the linear mixing lines between the major ions in the sub-aquifers (Fig. 6). The lower sub-aquifer is interpreted to represent mainly natural water from floods, whereas in the groundwater closer to surface, the contaminant component is higher. 
The main anthropogenic source is from agricultural activities including fertilizer applications. The agricultural activity affects mainly the nitrate concentration of recharging water. The nitrate salts are highly soluble and are easily flushed towards the water table. The nitrate concentration has increased over the years, mainly in the last 10 years, in all three aquifer units (Fig. 9). In the local lens it ranges between 100 and $300 \mathrm{mg} / \mathrm{l}$ and in the upper subaquifer it is over $50 \mathrm{mg} / \mathrm{l}$. This process of nitrate concentration increase due to excess fertilizers was found in many other places (Datta et al., 1997; Flipse and Bonner, 1985; Sadek and Abd El-Samie, 2001). The nitrate concentrations and the rate of increase are higher the closer the sub-aquifer is to surface. Increase of the nitrate concentration in the upper sub-aquifer (Marzeva 10 and 4 wells), indicates contamination from agriculture (Fig. 8). The stable low nitrate and $\mathrm{Cl}$ concentration in the Marzeva 9 well, which extracts water from the lower sub-aquifer, indicates that the recharge irrigation water has not significantly affected this well yet.

The reduction of $\mathrm{NO}_{3} / \mathrm{Cl}$ ratio from the irrigation + fertilizer water, through the ceramic cups and to the local lens (Fig. 7(c)) is caused by plant uptake of $\mathrm{NO}_{3}$ and maybe some denitrification.

The potassium concentrations follow the same trend, with higher concentrations in the shallow lens. The $\mathrm{K} / \mathrm{Cl}$ ratio of the water samples indicates reduction of $\mathrm{K}$ concentration during the subsurface flow (Fig. 7(b)). This reduction may be caused also by plant uptake as well as sorption by clays. The large variability of the potassium concentration, especially in the lens close to surface (Fig. 10), may be related to these reasons.

The $\mathrm{K}$ in the fertilizers comes in part as $\mathrm{KCl}$ and in part as $\mathrm{KNO}_{3}$. Farmers in the Arava Valley commonly use $\mathrm{K}$ as $\mathrm{KNO}_{3}$ in most of the growths. The chloride from applied fertilizers appears to be insignificant in comparison to the chloride from the irrigation water itself. This is indicated by (1) the samples of irrigation + fertilizer water have high $\mathrm{K}$ concentrations but the same $\mathrm{Cl}$ concentrations as the irrigation water (Table 1), and (2) the ratio $\mathrm{Na} / \mathrm{Cl}$ in the irrigation water, irrigation + fertilizer water, and ceramic cups water are in the same range as in unpolluted and polluted groundwater $(0.8-1)$ (Fig. 7(a)). These data confirm that the main source of $\mathrm{Cl}$ comes from irrigation water after evapotranspiration.

Another contaminant found in the shallow groundwater is the TOC. The TOC concentration in the local lens is more than tenfold higher than the concentration in unpolluted wells. The concentration in the upper sub-aquifer is only slightly higher than the unpolluted wells. The TOC could be from natural or agricultural vegetation, manure and sewage. The decrease of TOC with depth could also be affected by adsorption or decomposition of the organic material during flow.

In the upper sub-aquifer there is a significant increase in the ion concentrations from south to north along the groundwater flow direction. The ion concentrations upgradient from the fields (Arava 22 well) are lower than the concentrations in the lower sub-aquifer (Fig. 7). The area between the up- and downgradient boreholes (Table 1) includes most of the cultivated fields and the sewage pools. This trend supports the other findings that the contamination is due to anthropogenic activity but it is still difficult to determine the contribution from the sewage.

The isotopic composition of $\mathrm{N}-\mathrm{NO}_{3}$ in groundwater depends on the source materials and subsequent biogeochemical alterations (Kohl et al., 1971; Heaton, 1986). In the present study, the potential sources are fertilizers, sewage, cattle manure that is spread on the fields, and organic crop remains. It is assumed that no significant denitrification altered the isotopic composition of nitrate because of the following reasons: (1) the similar nitrate concentrations $(\sim 170 \mathrm{mg} / \mathrm{l})$ of the local groundwater lens and the calculated concentration from irrigation + fertilizers recharge water (calculation was done by dividing the excess amount of $\mathrm{N}$-fertilizers by the excess irrigation water), (2) dissolved oxygen concentrations between 3.1 and $6.9 \mathrm{mg} / \mathrm{l}$ (Oren, 2003) in the groundwater lens does not imply favorable conditions for denitrification, and (3) the $\delta^{15} \mathrm{~N}$ values of nitrate in the deep relatively unpolluted groundwaters are relatively low, indicating that denitrification is not the main reason for the relatively low nitrate concentrations in those wells. The somewhat high $\delta{ }^{15} \mathrm{~N}$ value and low $\mathrm{NO}_{3} / \mathrm{Cl}$ ratio of Arava 6 well may indicate local denitrification.

The fertilizer nitrates used in the area have $\delta{ }^{15} \mathrm{~N}$ values close to zero ( 0.9 and $2.7 \%$, Table 1$)$. These results are compatible with other studies (Kaplan and Magaritz, 1986; Gormly and Spalding, 1979; 
Flipse and Bonner, 1985). The drainage water from the ceramic cups in the root zone $(20$ and $40 \mathrm{~cm}$ depth) has the same and slightly higher $\delta^{15} \mathrm{~N}$ values, 2.7 and $3.3 \%$, respectively. This could be due to reduced $\mathrm{N}$ (like $\mathrm{NH}_{4}$ ) in the fertilizers. The low values of $\delta^{15} \mathrm{~N}$ (close to zero) characterize the nitrate contribution from fertilizers and are an important end member in cases of a mixing between different sources.

$\delta{ }^{15} \mathrm{~N}$ values of 'unpolluted' wells and undisturbed soil vary between 7 and $12 \%$. This range of values is similar to those observed in soils and uncontaminated groundwater in some other arid regions (e.g. Mojave Desert; Densmore and Böhlke, 2000); however, it is not clear why the soil leachate values are higher than the unpolluted groundwater values. In the absence of other information, and because the number of samples of both types is limited, it is tentatively concluded that the unpolluted groundwaters more likely represent average natural recharge than the soil leachates.

Compared to the unpolluted groundwaters (with $\delta{ }^{15} \mathrm{~N} \approx 7 \%$ o), waters that appear to be artificially enriched in nitrate (based on the chemical evidence) have even a higher variability of $\delta^{15} \mathrm{~N}$ values that probably indicate several different anthropogenic sources. The lower $\delta{ }^{15} \mathrm{~N}$ values (around 4.9-6.2\%o) in some of the shallow boreholes are similar to those found in agricultural areas using large amounts of artificial fertilizers. The highest values (up to $15 \%$ o) are similar to those found in areas using manure fertilizer or domestic wastewater.

The polluted boreholes may be divided into two groups by isotopic composition-upgradient and downgradient with respect to the sewage ponds. The upgradient boreholes have relatively low $\delta{ }^{15} \mathrm{~N}$ values (4.9-6.2\%o) that are consistent with substantial fertilizer inputs. The somewhat higher $\delta^{15} \mathrm{~N}$ values of groundwater nitrate compared to the fertilizer values (4.9-6.2 and 0.9-2.7\%o, respectively), which is the general situation in many cases, may be explained in part by volatilization of reduced $\mathrm{N}$ fertilizers (e.g. ammonium and urea) before being nitrified, or by soil denitrification (Böhlke, 2002; Kreitler, 1979; Böhlke and Denver, 1995; Fogg et al., 1998; Kendall and McDonnell, 1998).

The downgradient boreholes have a wider range of $\delta^{15} \mathrm{~N}$ values, between 5.5 and $14.8 \%$, which may indicate varying amounts of additional contamination from sewage or manure sources, both of which are present in the area between the upgradient and downgradient wells. Assuming denitrification has not had a major effect; it is possible to outline various hypothetical mixtures of nitrate sources of groundwater (Fig. 11(a)). Line A represents a hypothetical mixture between natural groundwater and excess irrigation + fertilizer water, and line B represents a hypothetical mixture between natural groundwater and a sewage or manure source. If there was only a sole source of nitrate contamination, it could be expected that all the samples would be sited on one line (A or B). In fact, most of the polluted groundwaters plot between these two lines, in an area of the diagram that would indicate mixtures of fertilizer and sewage/manure sources.

There is no correlation between the nitrate and chloride concentrations and $\delta{ }^{15} \mathrm{~N}$ values (Fig. 11), nor between the different sub-aquifers and the isotopic values. These observations indicate that the nitrate contamination sources are similar in the different subaquifers.

\section{Summary}

The present study shows that intensive irrigation and fertilization in the arid environment of Arava Valley significantly affects the quantity and quality of groundwater recharge. Low irrigation efficiency of about $50 \%$ contributes approximately 3.5-4 million $\mathrm{m}^{3} /$ year to the hydrological system. During the research period, the natural recharge from floods was found to be negligible in relative to irrigation water.

The two main contamination processes are: (1) salinization due to circulation of salts dissolved in the irrigation water itself, mainly chloride, sulfate, sodium and calcium (2) direct input of nitrate and potassium from fertilizers and sewage ponds.

The salt concentrations in the evaporative excess water exceed the drinking water standard. Nitrate concentrations increased in the aquifer, mainly during the last 10 years. The most rapid increases and highest current nitrate concentrations occurred in the shallow parts of the aquifer. They exceed the standard for drinking water in a shallow local perched lens ranging between 100 and $300 \mathrm{mg} / \mathrm{l}$, and in the upper subaquifer are over $50 \mathrm{mg} / 1$. Chemical and isotopic data 
indicate that a major source of nitrate is from fertilizer $\mathrm{N}$ in the excess irrigation water. Other sources could be, in places, from nearby sewage ponds and/or manure that is spread on the fields. More evidence of contamination in groundwater due to the agricultural activity includes high concentrations of potassium and TOC.

\section{Acknowledgements}

This work was supported by the Arava Drainage Authority; we are grateful to A. Shacham for helpful information and for financing part of the study. We thank D. Stiber, O. Yoffe, Y. Deutsch, and I. Cupelovich (Geological Survey of Israel) for help with the chemical analyses, B. Shilman (Geological Survey of Israel) for the oxygen-18 measurements, I. Carmi (Weizmann Institute) for the tritium measurements and D. Eni (Ministry of Health) for the TOC measurements. The nitrogen isotopic analyses carried out at the USGS laboratory are highly appreciated. We thank H. Hemo and Y. Rafael (Geological Survey) for their help in the field, B. Cohen and H. Nezer-Cohen (Geological Survey) for the graphical assistance, and B. Catz for proofreading of the paper. We are very grateful to the En Yahav residents for their cooperation.

\section{References}

Albus, W.L., Knighton, R.E., 1998. Water quality in a sand plain after conversion from dryland to irrigation: tillage and cropping systems compared. Soil and Tillage Research 48, 195-206.

Allaire-Leung, S.E., Wu, L., Mitchell, J.P., Sanden, B.L., 2001. Nitrate leaching and soil nitrate content as affected by irrigation uniformity in a carrot field. Agricultural Water Management 48, 37-50.

Bar-Yosef, B., Kremer, S., Ben-Basat, S., 1982. Fertilization combined with drip irrigation in north Arava. 3. Lying tomato, type 675. Soil and Water Institute, Bet Dagan, and the Regional Experiment Station in Yotvata.

Böhlke, J.K., 2002. Groundwater recharge and agricultural contamination. Hydrogeology Journal 10, 438-439.

Böhlke, J.K., Coplen, T.B., 1995. Interlaboratory Comparison of Reference Materials for Nitrogen-Isotope-Ratio Measurements, In: Reference and Intercomparison Materials for Stable Isotopes of Light Elements, International Atomic Energy Agency, IAEA TECDOC 825 , pp. $51-66$.
Böhlke, J.K., Denver, J.M., 1995. Combined use of groundwater dating, chemical, and isotopic analyses to resolve the history and fate of nitrate contamination in two agricultural watersheds, Atlantic coastal plain, Maryland. Water Resources Research 31, 2319-2339.

Böhlke, J.K., Wanty, R., Tuttle, M., Delin, G., Landon, M., 2002. Denitrification beneath the recharge area and discharge area of a transient agricultural groundwater nitrate plume in Minnesota. Water Resources Research 30 (10), 1-26.

Bowman, W.W., Hughes, M.B., 1981. Proportional Counting Techniques for Routine Tritium Analysis at Environmental Levels, In: Methods of Low-level Counting and Spectrometry, International Atomic Energy Agency, Vienna, pp. 353-358.

Criss, R.E., Davisson, M.L., 1996. Isotopic imaging of surface water/groundwater interactions, Sacramento valley, California. Journal of Hydrology 178, 205-222.

Datta, P.S., Deb, D.L., Tyagi, S.K., 1997. Assessment of groundwater contamination from fertilizers in the Delhi area based on O-18, $\mathrm{NO}_{3}$ and $\mathrm{K}$ composition. Journal of Contaminant Hydrology 27, 249-262.

Davisson, M.L., Criss, R.E., 1993. Stable isotope imaging of a dynamic groundwater system in the southwestern Sacramento valley, California, USA. Journal of Hydrology 144, 213-246.

Densmore, J.N., Böhlke, J.K., 2000. Use of nitrogen isotopes to determine sources of nitrate contamination in two desert basins in California. In: Reichard, E.G., Hauchman, F.S., Sancha, A.M. (Eds.), Interdisciplinary Perspectives on Drinking Water Risk Assessment and Management, Int. Assoc. Hydrol. Sci. Publ. 260, pp. 63-73.

Eaton, A.D., Clesceri, L.S., Greenberg, A.E. (Eds.), 1995. Standard Methods for the Examination of Water and Wastewater, American Public Health Association, Washington, pp. 5.16-5.19.

EPA (United State Environmental Protection Agency), 1996. Drinking Water Regulations and Health Advisories, Environmental Protection Agency, Washington, DC.

Flipse, W.J., Bonner, F.T., 1985. Nitrogen-isotope ratios of nitrate in groundwater under fertilized fields, Long Island, New York. Groundwater 23, 59-67.

Fogg, G.E., Rolston, D.E., Decker, D.L., Louie, D.T., Grismer, M.E., 1998. Spatial variation in nitrogen isotope values beneath nitrate contamination sources. Groundwater 36, 418-426.

Freeze, R.A., Cherry, J.A., 1979. Groundwater, Prentice-Hall, Englewood Cliffs, NJ, p. 604.

Gat, J.R., Galai, A., 1982. Groundwaters of the 'Arava Valley': an isotopic study of their origin and interrelationships. Journal of Earth-Sciences 31, 25-38.

Gormly, J.R., Spalding, R.F., 1979. Sources and concentrations of nitrate-nitrogen in groundwater of the central platte region, Nebraska. Groundwater 17, 291-301.

Hadas, A., Sagiv, B., Haruvy, N., 1999. Agricultural practices, soil fertility management modes and resultant nitrogen leaching rates under semi-arid conditions. Agricultural Water Management 42, 81-95.

Hansen, E.A., Harris, A.R., 1975. Validity of soil-water samples collected with porous ceramic cups. Soil Science Society 39, 528-536. 
Heaton, T.H.E., 1986. Isotopic studies of nitrogen pollution in the hydrosphere and atmosphere: a review. Chemical Geology 59, 87-102.

Hem, J.D., 1985. Study and Interpretation of the Chemical Characteristics of Natural Water, United States Geological Survey Water. Supply Paper 2254, pp. 1-263.

Hudak, P.F., 2000. Regional trends in nitrate content of Texas groundwater. Journal of Hydrology 228, 37-47.

Kaplan, N., Magaritz, M., 1986. A Nitrogen-isotope study of the sources of nitrate contamination in groundwater of the pleistocen coastal plain aquifer, Israel. Water Resources 20, $131-135$.

Kendall, C., McDonnell, J.J. (Eds.), 1998. Isotope Tracers in Catchment Hydrology, Elsevier Science, Amsterdam, pp. 519-576.

Kohl, D.H., Shearer, G.B., Commoner, B., 1971. Fertilizer nitrogen: contribution to nitrate in surface water in a corn belt watershed. Science 174, 1331-1334.

Kreitler, C.W., 1979. Nitrogen-isotope ratio studies of soils and groundwater nitrate from alluvial fan aquifers in Texas. Journal of Hydrology 42, 147-170.

Naor, H., Granit, Y., 1991. Central Arava: updating the hydrological and operational situation of the aquifers and wells. Water section-Hydrology Department, TAHAL (in Hebrew).

Naor, H., Granit, Y., 2000. Central Arava: updating the hydrological and operational situation of the aquifers and wells, and forecasts until 2004. Water section-Hydrology Department, TAHAL (in Hebrew).

Nolan, B.T., 2001. Relating nitrogen sources and aquifer susceptibility to nitrate in shallow groundwaters of the United States. Groundwater 39, 290-299.

Oenema, O., Boers, P.C.M., van Eerdt, M.M., Fraters, B., van der Meer, H.G., Roest, C.W.J., Schroder, J.J., Willems, W.J., 1998. Leaching of nitrate from agriculture to groundwater: the effect of policies and measures in the Netherlands. Environmental Pollution 102, 471-478.
Oren, O., 2003. Contamination Process of Groundwater Under Cultivated Fields in an Arid Environment, Central Arava Valley. MA Thesis, Ben Gurion University of the Negev, Beer Sheva (in Hebrew, English Abst.).

Rhoads, J.D., Loveday, J., 1990. Salinity in irrigated agriculture. In: Stewart, B.A., Nielsen, D.R. (Eds.), Irrigation of Agricultural Lands, ASA Monograph No. 30, Am. Soc. Agron., Madison, WI, pp. 1089-1142.

Rodvang, S.J., Simpkins, W.W., 2001. Agricultural contaminants in Quaternary aquitards: a review of occurrence and fate in north America. Hydrogeology Journal 9, 44-59.

Sadek, M.A., Abd El-Samie, S.G., 2001. Pollution vulnerability of the Quaternary aquifer near Cairo, Egypt, as indicated by isotopes and hydrochemistry. Hydrogeology Journal 9, 273-281.

Simmers, I., 1997. Groundwater recharge principles, problems and developments. In: Simmers, I., (Ed.), Recharge of Phreatic Aquifers in (semi-) Arid Areas, A.A. Balkema, Rotterdam, pp. $1-18$.

Singh, B., Singh, Y., Sekhon, G.S., 1995. Fertilizer-N use efficiency and nitrate pollution of groundwater in developing countries. Journal of Contaminant Hydrology 20, 167-184.

Stigter, T.Y., Van Ooijen, S.P.J., Post, V.E.A., Appelo, C.A.J., Carvalho Dill, A.M.M., 1998. A hydrogeological and hydrochemical explanation of the groundwater composition under irrigated land in a Mediterranean environment, Algarve, Portugal. Journal of Hydrology 208, 262-279.

Yechieli, Y., Starinsky, A., Rosenthal, E., 1992. Evolution of brackish groundwater in a typical arid region: northern Arava rift valley, southern Israel. Applied Geochemistry 7, 361-374.

Yechieli, Y., Bein, A., Haliz, L., 1997. The geochemistry of the groundwater in Central Arava. GSI Report GSI/30/96 (in Hebrew).

Yechieli, Y., Bein, A., Burg, A., Yarom, I., 2001. The impact of flash floods interception on the Arava shallow groundwater: characterization of the interrelationships in the natural and disturbed systems. GSI Report TR-GSI/11/2001 (in Hebrew). 